\title{
Google Autocomplete Search Algorithms and the Arabs' Perspectives on Gender: A Case Study of Google Egypt
}

\author{
Linda S. Al-Abbas ${ }^{a}$ \\ lindaalabbas84@yahoo.com \\ Department of English Language and Literature, \\ Middle East University, Jordan \\ Ahmad S. Haider ${ }^{b}$ \\ ah_haider86@yahoo.com \\ Department of English Language and Translation, \\ Applied Science Private University, Jordan \\ Riyad F. Hussein \\ rfhussein@hotmail.com \\ Department of English Language and Translation, \\ Applied Science Private University, Jordan
}

\begin{abstract}
Search engines have become an essential part of everyone's life, with Google being the most popular. Google Search provides the autocomplete feature for faster and easier search results, offering 10 top suggestions at a time, and these may influence how users view different social groups. Different scholars have explored online discourse to reveal stereotypes about certain groups. However, little or no attention has been paid to technological affordances to reveal broader gender biases and stereotypes in the Arab World. This study examines how Google autocomplete searches can reflect the Arabs' perspectives on gender. Google Egypt is selected since it is top-rated in the number of internet users. Google is queried by entering a combination of Arabic question words followed by the Arabic equivalents for men and women. One hundred and ninety questions were generated and categorized according to the qualities they referenced. The most common assumptions about men indicate that they are cheaters, liars, self-dominant, emotionally strong, and smarter than women. They are also stereotyped as being more likely to admire young women, prefer sons over daughters, and desire polygamy. Women, on the other hand, are stereotyped as plotting, materialistic, emotional, and sensitive. The study concludes that since such generalizations may entail exaggerations and are not evidently right all the time, one must be careful about adopting such stereotypes and making them part of each gender's views of the other. Bearing in mind the perpetuating function that technology may have of existing stereotypes and social norms, users and developers of Google alike must pay more attention to gender biases that algorithms may establish and disseminate.
\end{abstract}

Keywords: Arabic; Google's Autocomplete; Anonymity; Stereotypes; Gender; Online Discourse

\section{INTRODUCTION}

It is a widely acknowledged truth that the Internet has facilitated communication between people, no matter how distant they are. With the computer-mediated communication systems, new platforms are created for users to get into contact with each other such as instant

\footnotetext{
${ }^{a}$ Main author

${ }^{b}$ Corresponding author
} 
messaging, emails, chat rooms, social network websites, online forums, and many others. The Internet also provides different web search engines that allow people to inquire about various issues. All that users need to do is to enter specific terms of the information they are trying to find for a web search query, and the results are then displayed in response. These engines impose no restrictions on the information searched for. This, in turn, raises concern over the way language is being used, especially that users are aware of the fact that their identities are hidden. This anonymity gives them the freedom to search for topics that they do not usually dare to raise or discuss with others, such as sexual issues that are considered taboos in their communities. Some people avoid asking questions that pertain to political and religious issues because of the sensitivity of such topics. Others feel curious to know about a certain topic, such as the other gender's interests, biological differences, medical information, or religious laws, but do not get satisfying answers or do not like to appear ignorant. For all this, the Internet offers people a private space to attain the unanswerable. It allows them to look for whatever they want with no restrictions on the language used.

Nowadays, search engines have become an important part of people's life. There are many search engines that are widely used by people, such as Bing, Yahoo, DuckDuckGo, Internet Archive, and many others. However, the most popular search engine worldwide is Google, with $92.62 \%$ market share as of June 2019 and more than 5.4 billion search queries every day (StatCounter, 2019). In fact, its dominance led users to use the term 'google' as an equivalent to "search." When one carries out a search, millions of results are displayed by web crawling from site to site. They are sorted through billions of web pages in order to find the most relevant for what one is looking for. Google Search provides a feature for faster and easier search results, which is the autocomplete search. Once users start googling what they are looking for, they can quickly find information with search predictions. These predictions are based on trending searches made by people for popular topics in a particular area, and they are not the answer to what is being searched for. It must be noted here that Google removes sexually explicit predictions that are not related to medical, scientific, or sex education topics. Hate and violence predictions against groups on the basis of race, religion, or other demographics in addition to dangerous or harmful activity involved in predictions are removed (Google, 2019).

Although one can simply choose not to select any suggestion from the search predictions, it seems that the auto-completion algorithms function in a forceful way that they intervene before users have completed typing. This, in turn, may result in unintended consequences; that is, it may draw people's attention to search for a specific suggestion that was not planned for. When the query is made about a certain social group or region, the suggestions given may reveal underlying stereotypes based on what people search for. Stangor (2000, p. 5) defines stereotypes as "beliefs about the characteristics of groups of individuals" They are usually created on the basis of gender, nationality, race and ethnicity, age, language, and so forth. Stereotypes deal with generalizations of traits that seem to be the most prominent for a particular group and distinguish them from other groups (Hilton \& Von Hippel, 1996). In fact, many stereotypes may reveal good features about a specific group, but they are pejorative in most cases. Although these stereotypes may be true to a certain degree, they may still entail exaggerations (Judd \& Park, 1993).

Among the stereotypes that are deeply embedded in cultures are those related to gender. They usually reflect ideas about femininities and masculinities, or in other words, how men and women dress, behave, or present themselves. Yet, it must be noted that these stereotypes vary among cultures and over time. Although the term gender may include different gender identities, the focus of the current paper is mainly on males and females since other gender identities are underrepresented in the Arab World (Al-Abbas \& Haider, 2020). 
This study is an attempt to investigate the stereotypes attached to men and women in the Arab World, particularly Egypt, by exploring the most frequent queries as predicted by Google autocomplete algorithms and categorizing the results according to the features they referenced. It mainly answers the following questions:

1. Does the predictive autocomplete function of Google propagate gender-based biases and stereotypes based on the suggestions it provides?

2. After categorizing the suggestions, what are the most frequent underlying stereotypes related to men and women in the Arab World?

Using Google's autocomplete function to uncover societal stereotypes was the primary concern of some previous studies. Baker and Potts (2013) conducted a study in which they investigated how Google autocomplete search algorithms suggested stereotypes about different groups, such as gay and black people identities, through a number of questions. They found that Google's predictions associate certain qualities with several social groups. They examined Google UK and recommended that further studies on Google searches from other countries in other languages be conducted to find if they can yield similar stereotypical representations of minority groups:

\footnotetext{
"We recognise that the use of English in searches - and of Google.co.uk to carry out these searches - has limited our results and analysis to western (Anglo-centric) stereotypes, and we would be eager to learn whether Google searches from other countries in other languages yield similar stereotypical representations of minority groups" (Baker \& Potts, 2013, p. 202).
}

In the same vein, Roy and Ayalon (2019) carried out a similar study to investigate how the predictors provided by the Google United States can reflect age and gender stereotypes when searching for information about older men and women. The study followed an inductive content analysis to categorize and interpret predictors in response to a number of search terms. The study found that queries about older men were mainly associated with romance and sexuality. In contrast, those for older women focused on changes in the body in addition to sexual and reproductive health.

As discussed above, different scholars have explored online discourse to reveal stereotypes about certain groups (see Baker \& Potts, 2013; Roy \& Ayalon, 2019). However, little or no attention has so far been paid to technological affordances to reveal broader gender biases and stereotypes in the Arab World to the best of the researchers' knowledge. Therefore, one of the research gaps that this study fills is working on Arabic data retrieved from search engines to examine the Arab's perspectives on gender.

\section{STEREOTYPES}

\section{GENDER STEREOTYPES}

According to the Office of the United Nations High Commissioner for Human Rights/ OHCHR (2014, p. 1), gender stereotypes can be defined as "a generalized view or preconception about attributes, or characteristics that are or ought to be possessed by women and men or the roles that are or should be performed by men and women." The same report defined gender stereotyping as "the practice of ascribing to an individual woman or man specific attributes, characteristics, or roles by reason only of her or his membership in the social group of women or men" (OHCHR 2014: 1). The concept of gender stereotypes and stereotyping has been thoroughly investigated (see Eagly \& Steffen, 1984; Eisend, 2019; Schein, 1973; Turner, 2010). It is highly related to the society's perspective on the roles women and men assume in life (Prentice \& Carranza, 2002). Stereotypes may shape perceptions, attitudes, and behaviors. 
Therefore, understanding them allows people to predict how women and men are perceived in their society and what behaviors are expected from women and men in their cultures (Burgess \& Borgida, 1999). Although stereotypes view both genders under investigation with some degree of favor or disfavor, they are mostly targeted at women (Office of the United Nations High Commissioner for Human Rights/ OHCHR, 2014). They usually maintain the power of men over women and hinder the advancement of women. Such distinction may result from the societal perception that women have lower status than men (Glick \& Fiske, 1996) and that they are inferior to men (Eagly \& Steffen, 1984). This makes the World a tough place for women in general and Arab women in particular because of the widely prevalent patriarchy and unlimited stereotypes (Said-Foqahaa \& Maziad, 2011).

Language plays a crucial role in creating power relations in society, and many people's actions, ideologies, and attitudes can be influenced by language (Haider, 2019a; Haider, 2019c; Haider \& Olimy, 2019). Wodak and Ludwig (1999) argue that language manifests and constitutes social processes and interaction. The study of discourse analysis and language in use entails analyzing media content (Alkhammash, 2020; Haider \& Hussein, 2020), presidential speeches (Haider, 2019b), and letters to the editor (Joharry, 2020) to mention some. In the present study, the investigated corpus includes Google autocomplete linguistic predictions that represent the most commonly searched information about a particular topic. These predictors reflect the societal beliefs and perceptions about the subject under discussion. This implies a view of language as a practice that is not only socially shaped but socially shaping of identities, relations, and ideologies (Fairclough, 2001).

\section{WOMEN STEREOTYPING IN THE ARAB WORLD}

Women in the Arab World have always been treated as inferior to men when it comes to their freedom and rights (Ghoussoub, 1987). They were subject to inequality throughout history, which was partly due to the misconception of religious beliefs. Some may argue that few Islamic laws are taken to the best advantage of men without paying attention to the conditions applied in some cases, such as polygamy (Rehman, 2007). This practice is justified in Islam and has some conditions. However, men usually do not adhere to the conditions attached to it like justice as they may unintentionally pay more attention to one of their wives over the others (Husain, Ahmad, Kara, \& Alwi, 2019). In most cases, they seem to utilize this right for the mere sexual urge (Zaidi, 2016). But all in all, polygamy is still quite rarely practiced in many Muslim societies (Al-Kholy, 2006).

Although Islam elevated women's status and instructed men to treat them kindly and gently, some go against these recommendations and treat women badly and cruelly. The number of cases of violence recorded against women is significantly increasing year by year. According to surveys conducted in Egypt, Palestine, and Tunisia, at least one out of three women is beaten by her husband (Douki, Nacef, Belhadj, Bouasker, \& Ghachem, 2003). What makes domestic violence worse is that men consider it a private matter and a justifiable reaction to the wife's misbehavior (Al-Badayneh, 2012).

Discrimination against Arab women also stems from the traditions that usually impose stricter restrictions on women when compared to men. In fact, Arab culture is generally characterized by being male-dominated and governed by tribal customs and traditions. Among these is that housework is traditionally seen as part of women's role (Hauser \& Featherman, 2013; Reagan \& Blaxall, 1976; Stangor, 2000). Even if the woman works outside the home, the domestic work's responsibilities are still assigned to her (Kluwer, Heesink, \& Van de Vliert, 1996; Perry-Jenkins \& Folk, 1994).

Marriage is considered an important step that could lead to societal membership in the Arab World. Families usually set marrying their daughters among their top priorities. 
Therefore, young females are traditionally required to dress and act in a way that should attract the attention of older women on social occasions and consequently secure the future husband. This is reinforced by the fact that a woman cannot ask a man to marry her, and she should only wait for men to propose to her. Even in some cases, girls are put under pressure to accept to marry at an early age out of fear that they may not have other opportunities in the long run (Abu Baker, 2003). What is also true is that men can set their own conditions about how their future wife should look in terms of skin and eye color, body, height, education, and many others. However, when it comes to women, they are usually convinced or forced to accept a proposing man regardless of his attributes, only to have the mission of marriage accomplished as early as possible. Generally speaking, Arab societies usually view unmarried women negatively and may also sympathize with them as they were deprived of getting married and having children. In contrast, this view is not held for unmarried men, and not having a wife remains a matter of choice. One of the main concerns for married women in the Arab World is having a male heir who will save the family line. This is considered a vital role that may lead women to keep having children year after year until they give birth to a son (El Gilany \& Shady, 2007a). In most cases, women feel the necessity to accept successive pregnancies because they know very well that failing to give birth to the awaited heir may place them under the threat of divorce or polygamy. Although science proved that men are the ones to determine the sex of the baby, most Arab men, especially the uneducated, tend to blame it on women. According to Goodwin (2003), few Muslim men, even the educated, accept that they are responsible for determining the gender of the child and not their wives. They even refrain and consider their wives worthless if they have only given them girls. It is worth noting that according to the researchers' observations as natives of the Middle East, this phenomenon is not as common as it was in the past.

Additionally, for a woman to be a good wife, she needs to serve her husband and get all his domestic needs done with no delay. Moreover, newly married women in the Arab culture are advised to be dressed well all the time to keep their husbands attached to them. In later stages, they are encouraged to give birth to a new baby for this purpose or simply as a way to solve any marital problem (Abu Baker, 2003). All this makes women obsessed with the idea of retaining their husbands in one way or another, especially that they know if they fail to do so, they will end up with divorce. Divorced women are socially stigmatized and seen as bad spouses and mothers more than divorced men (Cohen \& Savaya, 1997). Although, in some cases, the reason behind divorce is the husband's physical abuse against his wife, women are still the ones to experience difficulties due to the prevailing social culture that condemns and puts all the blame on divorced women in the Arab World. Additionally, in low-income families, the situation gets even worse since a divorced woman adds an economic burden to her family, especially if her children join her. These facts make women think twice before seeking a divorce, not to forget that in many cases, they are threatened of deprivation of children by their ex-husbands or exploited financially by their families if they have an income source (Douki et al., 2003).

There are many areas in which women have been subject to inequality, such as education, employment, and politics. Women neither enjoy equal political or civil rights with men, nor do they get the same education and job opportunities (Ottaway, 2004). Although there were many campaigns that called for equality between both sexes in this regard, women's participation in decision-making or employment in positions of power is still limited until the present day. It is not surprising that no woman has ever held the position of head of state in the Arab World. Al-Maaitah, Al-Maaitah, Olimat, and Gharaibeh (2011) investigated the political participation of women in Arab countries. They identified the challenges that women face and found that there are cultural factors that hinder their empowerment in politics. These are mainly linked to the roles that are culturally assigned to each gender where women are responsible for 
the family in the household, while men's duties usually take place in the public sphere. What is also noticed in the Arab World is that even if women work outside the home, they increasingly encounter the problem of low pay very often, and this becomes clearer when they are compared to their male counterparts at workplaces (Rubery, 2017).

Women in the Arab World have different negative images that are continually emphasized in the Arab media. These include depicting them as being illiterate, of limited intellectual capability, inexperienced, materialistic, opportunistic, weak, or dependent (Allam, 2008).

\section{METHODOLOGY}

This study is qualitative and quantitative in nature. It aims at investigating the stereotypes attached to both genders under investigation among Arab speakers. This is achieved by categorizing the most frequently asked questions on Google, as the autocomplete algorithms suggest. These categories are then given percentages in order to find the most common traits among men and women and then determine the stereotypes they reflect.

\section{WHY GOOGLE EGYPT?}

Google search engine provides a feature of exploring results by region, and this was necessary for the purpose of this study in order to highlight Arabs' perspectives on gender. Therefore, the data were mainly collected from Google Egypt. The reason for choosing this country, in particular, is that it is top-rated among the Arab countries in terms of the number of internet users according to the Internet World Stats estimated on June 30, 2019 (Internet World Stats, 2019). This made its selection a matter of generalizability.

\section{DATA COLLECTION}

As was mentioned in the introduction, stereotypes are generalizations about different groups of people based on different characteristics, such as gender, ethnicity, age, and many others. This study is concerned with gender stereotypes because of the persisting issue of gender inequality in the world in general and the Arab World in particular. The researchers typed

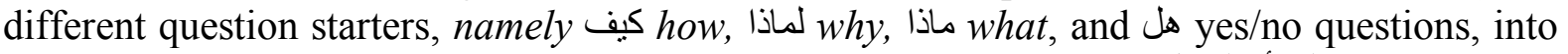
Google Egypt followed by the singular Arabic forms of woman/man المر أة/الرجل الرجل forms women/men النساء|/لرجال. Based on the most frequent questions searched by users, the Google autocomplete feature provides 10 top suggestions at a time. Therefore, the number of elicited questions for each question starter was 10. However, for the Arabic word $a$ woman, there was a problem regarding the middle glottal stop. Some people tend to type the word without the Hamza - that is the sign that elongates the sound P - just like المراة a woman. This made the researchers include double the number of questions as results for the Arabic singular form for validity purposes. In total, the number of the elicited questions for each investigated word was 40 except for the singular form of the Arabic المرأة a woman. The number of elicited questions from Google for man/men was 80, and 120 for woman/women. There were some cases where the same question was produced twice and so was counted only once. As a result, ten questions were deleted from the result of woman/women, and only 110 questions for woman/women were considered. It is worth noting that all questions were collected verbatim, even though some seemed not to follow the Arabic VSO word order and style. 


\section{DATA VALIDITY}

The researchers turned off Web History in Google settings to remove factors other than locations from Google's suggestions. The researchers also asked different friends from various places in Egypt to enter the different question starters with the Arabic equivalents for men/women to ensure that they will get the same results and found that the results were replicated. Since the Google autocomplete suggestions are continually changing, it must be noted that the data were gathered in September 2019.

\section{ANALYSIS AND DISCUSSION}

This section presents the findings related to the most frequently asked questions on Google regarding both genders under investigation. These findings are then analyzed to find the most common stereotypes towards men and women in the Arab World.

\section{STEREOTYPES ATTACHED TO MEN}

Since the words man/men represent the same group, the elicited questions for both were combined in one Table totaling 80 . The researchers classified them into seven categories according to the topic, as shown in Table (1) below.

TABLE 1. Categories of suggestions related to man/men in Google Egypt

\begin{tabular}{|c|c|c|c|c|c|}
\hline \multirow{2}{*}{ Category } & \multicolumn{3}{|c|}{ Selected Examples for Discussion } & \multirow{2}{*}{$\begin{array}{l}\text { No. } \\
\text { of Qs }\end{array}$} & \multirow{2}{*}{$\%$} \\
\hline & No. & Arabic & English & & \\
\hline \multirow{6}{*}{ Gender Inquiries } & 1 & هل الرجال يبكون & do men cry & \multirow{6}{*}{36} & \multirow{6}{*}{$45 \%$} \\
\hline & 2 & ل لماذا الرجل يخون & why does a man cheat & & \\
\hline & 3 & لماذا الرجال يكذبون & why do men lie & & \\
\hline & & & & & \\
\hline & 4 & لـادا الرجال التزر دحاء من & $\begin{array}{l}\text { why are men smarter than } \\
\text { women }\end{array}$ & & \\
\hline & 5 & كيف الرجل يطول & How can a man get taller & & \\
\hline Biological & 6 & كيف الرجل يحدد نوع الجنين & $\begin{array}{l}\text { how does a man determine } \\
\text { the gender of the baby }\end{array}$ & 15 & $\begin{array}{c}18.8 \\
\%\end{array}$ \\
\hline \multirow{2}{*}{ Relationships } & 7 & كيف الرجل يسمع كلام زوجته & $\begin{array}{c}\text { how does a man listen to his } \\
\text { wife }\end{array}$ & \multirow{2}{*}{8} & \multirow{2}{*}{$10 \%$} \\
\hline & 8 & كيف الرجل يعرف انه عقيم & $\begin{array}{l}\text { How does a man know he is } \\
\text { infertile }\end{array}$ & & \\
\hline \multirow{3}{*}{ Religious } & 9 & هل الرجال افضل من النساء في & $\begin{array}{l}\text { are men better than women } \\
\text { in Islam }\end{array}$ & \multirow{4}{*}{6} & \multirow{3}{*}{$7.5 \%$} \\
\hline & 10 & ماذا تعني الرجال قو امون على & $\begin{array}{l}\text { what does it mean that men } \\
\text { are the protectors and } \\
\text { maintainers of women }\end{array}$ & & \\
\hline & 11 & ل لماذا الرجال يحبون التعدد & Why do men like polygamy & & \\
\hline \multirow[b]{2}{*}{ Sexual } & 12 & لماذا الرجال يحبون القدم & why do men like feet & & \multirow[b]{2}{*}{$7.5 \%$} \\
\hline & 13 & $\begin{array}{c}\text { لماذا الرجال بحبون الفتاة } \\
\text { الصغيرة }\end{array}$ & $\begin{array}{l}\text { why do men like young } \\
\text { women }\end{array}$ & 6 & \\
\hline language & 14 & ماذا يسمى الرجال والنساء الذين لاء لهم & $\begin{array}{l}\text { What are unmarried men } \\
\text { and women called }\end{array}$ & 5 & $6.2 \%$ \\
\hline \multirow[t]{2}{*}{ Zodiac Signs } & 15 & ماذا يحب الرجل العقرب في & $\begin{array}{l}\text { What does a Scorpio man } \\
\text { like in a woman }\end{array}$ & 4 & $5 \%$ \\
\hline & & Total & & 80 & $100 \%$ \\
\hline
\end{tabular}

Table (1) demonstrates that the category that recorded the highest percentage (45\%) of the total number of Google suggestions was gender inquires. These may include general questions about what men like or dislike 'do men like strong women?', what they prefer or what they don't 'do men prefer black or blonde hair?', how they behave in general or in certain situations 'what does a man do after separation?', or about traits that they are believed to have 
'why do men lie?'. It cannot be said that these questions are asked only by women to know about the other gender. It can be the case that men ask about issues that are usually referenced to them, as in 'how does a man become taller?' The number of questions in this category is 36, but only those that are clearly stereotypical are discussed.

The suggestions offered by Google autocomplete function reflect some generalizations about men. Example (1) 'do men cry?' presupposes that men are emotionally strong when compared to women and usually do not cry over any matter since shedding tears is taken to be a weakness and feminine behavior. In fact, even boys are told not to cry from a very young age because this is not considered part of their masculinity, and 'real men' usually do not cry. Different studies have examined whether men and women experience emotions the same way and why men are less likely to show them when compared to women (see de Boise, 2015). Since the focus of the elicited question is related to crying, it seems that the issue is related to how men tend to repress specific emotional displays in some particular contexts and under some conditions. Hearn (1993) argues that "what is remarkable is not so much that men cry [in organizations], but that this crying itself is seen as remarkable" (Hearn, 1993, p. 143). This appears to be common across different cultures (Fischer \& Manstead, 2000). However, this stereotype has a negative impact on both boys and men as it prevents them from expressing their emotions of sadness, depression, or loss in front of others in an attempt to prove their masculinity in the society where they live.

Example (2) 'why does a man cheat?' also implies a stereotype about men. This suggestion stereotypes men as being cheaters, although this may be true for women as well. However, this may be justified by the prevailing concept in the Arab World that men are not to be condemned as much as women for this act. On the contrary, some people may put the blame on wives for not being able to keep their husbands or not fully performing their household duties. Some others may accuse the woman of failing to fulfill all her husband's desires, whether sexually or psychologically. Therefore, he starts seeking ways to compensate for what he lacks in his marital relationship. On the other hand, if any woman is reported to be unfaithful to her husband, no justifications are given to her, but simply be condemned as immoral.

In the same vein, men are portrayed as liars, according to example (3) 'why do men lie?'. This trait is not exclusive to men as all people, regardless of their gender, tend to lie to reap the benefit or avoid unpleasant consequences. Nevertheless, this question stereotypes men as being more likely to lie than women. This generalization may have its grounds in reality, as many studies on lying showed (Dreber \& Johannesson, 2008; Kajackaite \& Gneezy, 2017; Serota, Levine, \& Boster, 2010).

Besides, men are stereotyped as being smarter than women based on example (4) 'why are men smarter than women?'. This may be based on the myth that men have larger brains, and therefore, are smarter. However, many studies showed that differences in brain size do not significantly affect learning or behavior (Davison, 2012; Wanjek, 2003). This issue of which gender is more intelligent is controversial and unsubstantiated among scholars. Some argue that there is no significant difference in the general intelligence between the two genders, while others argue for slightly greater intelligence for males, and others claimed that women are more intelligent than men. Nevertheless, the researchers did not find a similar question in the data related to women, and this indicates that men are seen as smarter than women in the Arab World.

There is a question that may indicate a stigma in the Arab World, which is linked to the expected height of men represented by example (5) 'How can a man get taller?'. Usually, women prefer a significant height difference between themselves and their spouses, with the latter being taller (Matharu, 2015). They may even refuse to be in a relationship in which they are taller than their male spouses. This may be attributed to the stereotypical connection that 
people often establish between height and strength; the taller a man is, the stronger he can be. This may lead some tall men to have more self-esteem than short ones because of the social disadvantages associated with shortness in the Arab culture. Ghanem (2011) stated that some men lack self-confidence if they are short, as this gives them a sense of losing control of their wives. Furthermore, women usually look for physical protection in a man, which does not seem to be achieved with a short husband.

The second highest category included questions about sex-specific biological issues. Most of these suggestions do not entail any stereotypical impact but represent what people wonder about regarding differences between both sexes; for example, there was a question about men getting pregnant that occurred four times with different wording. Similarly, people inquired about the possibility of men having a womb. Such questions may be the result of hearing lately about very few cases of men giving birth to babies, the most common may be that of the American Beatie who had gender reassignment surgery in 2002 (Mohler Jr, 2015). It must be noted, however, that such surgeries are very rare and not generally acceptable by the Arab societies. They may view the idea of gender switch sarcastically or even use it in movies for comedy effects as in the Egyptian film, Miss Hanafi, that was released in 1954 about a man who goes through an accidental sex change and becomes pregnant.

There is a question in this category; however, that draws one's attention back to what was mentioned earlier in the literature regarding the sex of the baby represented in example (6) 'how does a man determine the gender of the baby?'. Although the question does not state which gender is preferred, the obsession with having a son in the Arab World resolves the issue (see Sharaf, Rashad, \& Mansour, 2019). In the Middle East and North Africa (MENA) region, son bias is highly prevalent, where sons are preferred over daughters (Ahmad Al-Akour, Khassawneh, Khader, \& Dahl, 2009; El Gilany \& Shady, 2007b). Many Arab men in the past used to blame their wives for not giving birth to a male baby, but with the scientific advancement and the spread of knowledge, Arab women started to defend themselves on the grounds that men are the ones responsible for determining the sex of the baby. However, some men in the Arab World still do not seem to subscribe to this notion. It appears that this topic captures Arabs' minds, and that is why this question was among the top suggestions offered by Google. One cannot tell if the inquirer is a male or female, as this question can be asked by members of both genders, each for a different purpose, as discussed above.

In the relationship category, which ranked third, people inquired about general issues related to marital life. One of the generalizations that stereotypes men in the Arab World is being self-dominant, represented in example (7) 'how does a man listen to his wife?'. Since the Arab community is historically seen to be patriarchal where males were regarded to be superior to females (Alomosh \& Al Hourani, 2017), it is considered a shame for a man to take orders from his wife or adhere to what she says. If he does so, the society around will mock him for being yielding and submissive to his wife. In some slang Arabic dialects, such as Jordanian and Palestinian, people describe such henpecked men as being arnab (rabbit) or kharoof (sheep), which both mean a man who is dominated by his wife. Such harsh comments enhance the desire for some Arab men to be the ones to decide and give orders rather than sharing thoughts and plans with their wives. On the other hand, women usually try to find ways to have their husbands wrapped around their little fingers. They even tend to brag about their ability to control their husbands and seem to be competing for who is more able to make her husband go her own way.

Another point that needs to be discussed regarding marital infertility is shown in example (8) 'How does a man know he is infertile?'. In the Arab World, when a couple gets married and the wife is late to conceive, they are placed under pressure by their families and relatives, although this delay may sometimes be preplanned. Some women think that the sooner they fall pregnant, the better their image will be for their husbands and in-laws. However, if 
the wife does not get pregnant in the first year, some people may start relating this to fertility problems. When this happens, the woman is usually the one to start seeking help from a gynecologist to make sure that she is able to conceive. This is because infertility is traditionally thought of as a woman's problem, although it is linked to men in many cases. Nevertheless, having a man diagnosed with infertility can be one of the most formidable challenges he can face. Some find it offensive even to have the topic raised or discussed with them. Although men are still stigmatized, they are most of the time absent from public talk around infertility. Generally speaking, women bear the greater burden of late pregnancy as they are the ones who ultimately either get pregnant or not. It must be noted that although this patriarchal notion has been changing recently, the stereotypical portrayal of men blaming women for childlessness still persists in some societies (Inhorn, 2013).

The next category in terms of the frequency of questions is related to religious issues. People often use search engines to inquire about some matters that they find inappropriate to ask in public, especially those related to inequality between men and women. Examples (9) 'are men better than women in Islam?' and (10) 'what does it mean that men are the protectors and maintainers of women?' are among the top asked questions on Google. In Islam, men are responsible for providing protection and sustenance for women because of their biological composition and endurance ability, as stated in the Holy Qur'an. However, some may give themselves the right to control women's personal and public rights (Kia, 2019). This emphasizes the dominating nature of some men and their constant desire to control women.

Arab men were also stereotyped as having the desire to marry more than one woman, as shown in example (11) 'Why do men like polygamy?'. Polygamy is a right given to men by the Islamic laws provided that they treat wives equally. Islam permits polygamy, but it does not force it. However, men seem to utilize this right for the mere sexual urge (Zaidi, 2016). Polygamy has been declining throughout the Muslim World. Yet, those who practice it may marry more than one woman, even if the first wife fulfills their needs. Even some monogamous men express their desire to have a second wife, but they may not afford the expenses of maintaining more than one family.

The next category contains questions about sexuality, as shown in examples (12) 'why do men like feet?' and (13) 'why do men like young women?'. Coming across such predictions while typing in Google search box, one can assume that men are foot fetish and fervent for young women. This may not be true all the time, though. Some men may admire younger women as they have firmer bodies; some may find women's feet sexy, but, all in all, such predictions cannot be generalized. There are men who prefer older women as they find them wiser and more focused on starting a family (Patrick, 2019). Moreover, some men do not find feet as appealing as some others. Having this particular body part in the data can be attributed to the fact that foot fetishism may be more prevalent than most other types of fetishistic behaviors (Aggrawal, 2009).

The other categories consisted of information about linguistic terms and features of certain zodiac signs, as shown in examples (14) 'What are unmarried men and women called?' and (15) 'What does a Scorpio man like in a woman?'. The linguistic questions were all about the name given to unmarried men and women with different wording. Regarding zodiac signs, it seems that Arabs are influenced by what zodiac signs tell about one's character, traits, and love compatibility. These are the aspects of zodiac signs that seem to attract Arabs the most based on the frequency of the questions suggested by Google. Horoscopes seem to get less attention, and this may be due to the fact that Islam forbids reading them for the purpose of foretelling what the future holds. 


\section{STEREOTYPES ATTACHED TO WOMEN}

With regard to women, 110 questions were elicited, as shown in the methodology section. The questions were grouped together under the same classifications, as shown in Table (2).

TABLE 2. Categories of suggestions related to woman/women in Google Egypt

\begin{tabular}{|c|c|c|c|c|c|}
\hline \multirow{2}{*}{ Category } & \multirow[b]{2}{*}{ No. } & \multicolumn{2}{|c|}{ Example } & \multirow{2}{*}{$\begin{array}{c}\text { No of } \\
\text { Qs }\end{array}$} & \multirow{2}{*}{$\%$} \\
\hline & & Arabic & English & & \\
\hline \multirow{5}{*}{ Religious } & 16 & لماذا النساء كيدهن عظيم & why do women have great guile & \multirow{6}{*}{38} & \multirow{6}{*}{$34.5 \%$} \\
\hline & 17 & لماذا المر أة ناقصة عقل ودين & $\begin{array}{l}\text { why is a woman deficient in } \\
\text { religion and mind }\end{array}$ & & \\
\hline & 18 & ل لماذا المر أة لا تتزوج اربع & $\begin{array}{l}\text { why doesn't a woman marry four } \\
\text { men }\end{array}$ & & \\
\hline & 19 & هل المر اة المطلقة لها عدة & $\begin{array}{l}\text { does a divorced woman need to } \\
\text { observe iddah (period of waiting) }\end{array}$ & & \\
\hline & 20 & ماذا تتزوج النساء في الجنة & Who do women marry in paradise & & \\
\hline \multirow{5}{*}{$\begin{array}{l}\text { Gender } \\
\text { Inquiries }\end{array}$} & 21 & لماذا النساء يحبون الذهب & why do women like gold & & \\
\hline & 22 & لماذا النساء يحبون التسوق & why do women like shopping & \multirow{4}{*}{35} & \multirow{4}{*}{$31.8 \%$} \\
\hline & 23 & ماذا صنعت المر أة في التاريخ & $\begin{array}{c}\text { what has a woman achieved } \\
\text { throughout history }\end{array}$ & & \\
\hline & 24 & لماذا المر اة لا تصبح قاضية & $\begin{array}{c}\text { why doesn't a woman serve as a } \\
\text { judge }\end{array}$ & & \\
\hline & 25 & لماذا المر أة تتأثر بالفراق اكثر & $\begin{array}{c}\text { why is a woman more affected by } \\
\text { separation than a man }\end{array}$ & & \\
\hline Biological & 26 & هل المرأة تحدد نوع الجنين & $\begin{array}{l}\text { does a woman determine the } \\
\text { gender of the baby }\end{array}$ & 25 & $22.7 \%$ \\
\hline Zodiac Signs & 27 & هل المراة الثور جميلة & Is a Taurus woman beautiful & 4 & $3.6 \%$ \\
\hline Linguistic & 28 & ماذا تسمى الدراة التي فقدت & $\begin{array}{l}\text { What is a woman who lost her } \\
\text { child called }\end{array}$ & 3 & $2.7 \%$ \\
\hline Relationships & 29 & كيف تجذب النساء إليك & How to attract women to you & 3 & $2.7 \%$ \\
\hline \multirow[t]{2}{*}{ Sexual } & 30 & ماذا تفعل المر اة مع زوجها في & $\begin{array}{c}\text { What does a woman do with her } \\
\text { husband in bed }\end{array}$ & 2 & $1.8 \%$ \\
\hline & & Total & & 110 & $100 \%$ \\
\hline
\end{tabular}

Table (2) illustrates that the category with the highest number of questions was the one concerning grievance or complaints about religious issues. It seems that Arab women have some concerns about their status and rights in Islam. However, such concerns are not usually brought up in social conversations as they are deemed taboos by many people, especially when it comes to questioning religious laws that were stipulated in the Qur'an and Sunnah. Therefore, web search engines provide free space for people to ask questions about religious issues that are moot for them. These questions, however, imply certain stereotypes about how society views women when they appear among the top predictions in search engines like Google. It must be noted here that some generalizations about women are based on a misunderstanding of religious texts. They may be in the form of phrases taken from Qur'anic verses and Hadiths that are used in everyday life without referring to their original meaning. Among these generalizations that are also suggested by Google is demonstrated in example (16) 'why do women have great guile?'. This expression was mentioned in the Holy Qur'an in a particular context. In fact, this description is strongly linked to women in everyday life that some men tend to use the exact words of the verse to denounce women.

Similarly, some people, especially men claim that women are deficient in religion and mind. This assumption turned out to be a stereotype that was emphasized by example (17) 'why is a woman deficient in religion and mind?' which was originally taken from a Hadith. Again, this is sometimes said to women if they act in a way that seems unacceptable to men and is usually quoted out of context. However, some people do not look at the Prophet's explanation 
of this Hadith, which clarifies that the deficiency in religion is that women are not required to pray or fast during their period, and the deficiency in mind is due to the fact that the testimony of two women equals the testimony of one man; in case one forgets, the other reminds her. This confirms the earlier findings of Allam (2008) who stated that Arab women are stereotyped as having limited intellectual capabilities.

Some questions in this category are not stereotypical but express what women wonder about regarding some issues that seem unfair to them. Women feel that they get fewer rights than men, as in the case of multiple marriages represented by example (18), 'why does not a woman marry four men?'. While polygamy is permissible in Islam, polyandry is not simply to preserve the lineage and determine the children's paternity. Also, example (19), 'does a divorced woman need to observe iddah (period of waiting)?' represents an inquiry about an Islamic rule regarding married women. In Islam, if a woman is divorced or her husband died, she needs to observe iddah during which she cannot marry another man. This is intended to identify the fatherhood of an offspring if the woman showed signs of pregnancy. However, men do not need to wait for a specific period of time after divorce or the death of their wives. Additionally, Allah promised righteous men to marry beautiful virgin women in paradise called "Houris" as a reward for their good deeds. This makes women wonder what reward they will receive as stipulated in example (20) 'who do women marry in paradise?'. Some commentators say that women will be granted beauty with which they will feel better than the Houris (Sabir, 2008).

The next category in terms of the number of questions is related to gender inquiries. As suggested by Google, these questions represent features that are said to be specific to one gender. They may imply stereotypes that are rooted in our society about women. For example, women are portrayed as being in love with gold, as suggested by example (21) 'why do women like gold?'. Scherhorn, Reisch, and Raab (1990) state that women like to buy jewelry with a highly visually attractive appearance. This does not necessarily indicate that women are materialistic, but they may think that collecting gold is a way that provides them with financial security in case of divorce or the death of their husbands. Some other women like to buy gold in order to boast about how much their husbands are spending on them. On occasions like weddings or public gatherings, women seem to be competing for who is wearing more gold. Not only do women like gold, but they also like shopping according to example (22) 'why do women like shopping?'. In fact, shopping can be seen as a female drive that makes women spend hours and hours in stores without getting bored. Shopping for women may be considered a leisure activity (Woodruffe, 1997) and an opportunity for self-expression, fantasy, and a little self-indulgence (Buttle, 1992). Most women like to have a variety of materials, especially those that keep them updated with the latest trends in the fashion world. This way, they can attract the attention of their husbands, families, and friends to be complimented for their style. Generally speaking, women's obsession with shopping is particularly attributed to their interest in the way they look and the image they want to maintain.

Among Google's suggestions in this group is a question that may be viewed as an underestimation of women. This is related to women's achievements throughout history as elicited in example (23) 'what has a woman achieved throughout history?'. Such a question did not appear when the group inquired about was men. This has to do with the distribution of roles of both genders. While men do several jobs and hold different positions in different spheres of life, women's place is usually seen to be at the home to take care of their children. This is consistent with Al-Maaitah et al. (2011) who found that women's responsibilities are usually restricted to the household. This impedes their chances of making history and excludes them from holding positions in public life.

With regard to jobs and chances, women frequently wonder about the reason for the impossibility of serving as judges, as shown in example (24) 'why does not a woman serve as 
a judge?'. This shows the inequality between men and women when it comes to serving as judges, although women in non-Muslim countries can exercise their rights freely in the areas of law and justice. This prohibition seems to be colored with patriarchal bias.

Women are also stereotyped as being more emotional than men, as shown in example (25) 'why is a woman more affected by separation than a man?'. Psychologically speaking, it may not be true that men experience emotions less frequently than women. This may be again, linked to the expectations for femininity and masculinity. According to the prevailing stereotypes in Arab societies, men are tough, powerful, unfeeling, and rational, while women are weak, sensitive, intuitive, and irrational. Such stereotypes may have a stronger influence on emotional expression than do biological factors.

The next category included questions about biological issues. These were mainly concerned with pregnancy that confirms how maternity naturally forms an essential part of a woman's life. There is one inquiry; however, that needs to be raised here indicated in example (26) 'does a woman determine the gender of the baby?'. With less probability, a similar question appeared in the data related to men represented in example (6) 'how does a man determine the gender of the baby'. As discussed above, most Arabs like to have male rather than female children. It seems that there is a conflict between husbands and wives on who is responsible for determining the gender of the baby, and each tries to blame it on the other to reduce the unpleasant consequences of not having a baby boy.

The other categories consisted of information about features of certain zodiac signs (example 27) 'Is a Taurus woman beautiful?', linguistic terms (example 28) 'What is a woman who lost her child called?', relationships (example 29) 'How to attract women to you?', and sexual information (example 30) 'What does a woman do with her husband in bed?'., These questions were very limited in number and did not entail any stereotypes and hence, will not be discussed as they cannot be generalizable.

To sum up, there were differences in the types of questions attached to each gender. The category that ranked first in terms of frequency of the questions for men was gender inquiries, while for women, it was religious inquiries. Religious inquiries strikingly did not attract people's attention that much when it comes to men. Regarding biological inquiries and zodiac signs features, both genders under investigation showed similar interests but were slightly higher for men. Sexual inquiries were higher for men than for women, whereas marriage inquiries only appeared in the men's data.

\section{SUMMARY AND CONCLUSION}

Google autocomplete algorithms provide faster and easier search results. However, the suggestions offered by this feature act in a forceful way that they intervene before users have completed typing. This may draw people's attention to search for a specific suggestion that was not planned for and hence, establish certain stereotypes about a particular group.

In this study, the questions that were posed with regard to men and women in the Arab World, particularly Egypt, emphasize that there are many gender stereotypes that are deeply rooted in Arab societies. The most common traits linked to men are that they are cheaters, liars, self-dominant, emotionally strong, smarter than women, and desire polygamy. Men were also stereotyped as being more likely to admire young women, and they prefer sons over daughters. Women, on the other hand, were stereotyped as plotting, materialistic, emotional, and sensitive. Considering that the category that ranked first for women was religious inquiries, it seems that some women in the Arab World have concerns about their standing and rights in Islam. This may be attributed to misunderstanding religious texts or being ignorant of the intended meaning behind some Islamic rulings. Since one's identity is kept hidden on search engines, googling such issues that are considered taboos in many Arab societies becomes easier and safer. What 
is more, the autocomplete function serves as an efficient mechanism to save people's time and effort. However, it can be viewed as a worrying indicator of how technology intrudes to complete users' thoughts. A quick word of caution is needed here. Stereotypes suggested by Google autocomplete are not always an accurate reflection of the collective perception. They may entail exaggerations and are not all the time valid. One must be careful before adopting such generalizations and making them part of each gender's perspectives of the other.

This paper points to the perpetuating function that technology may have regarding existing stereotypes and social norms. Yet, that change is happening due to the fact that preconceived ideas about gender are being questioned in the first place, provided the anonymity feature of the Internet and despite their common sense or tabooed nature. Having this sort of 'conversation' with Google helps to both perpetuate and disrupt taken-for-granted ideas shared in a community. This cautions users and developers of Google alike to gender biases that algorithms may establish or disseminate.

For future research, this study can be replicated using other search engines or websites like YouTube. Other languages and geographical contexts can be examined as well to determine gender biases or other issues that reflect differences between cultures.

\section{ACKNOWLEDGMENT}

The authors are grateful to the Middle East University, Amman, Jordan for the financial support granted to cover the publication fee of this research article.

\section{REFERENCES}

Abu Baker, K. (2003). Marital problems among Arab families: Between cultural and family therapy interventions. Arab Studies Quarterly, 25(4), 53-74.

Aggrawal, A. (2009). Forensic and medico-legal aspects of sexual crimes and unusual sexual practices. Boca Raton: CRC Press.

Ahmad Al-Akour, N., Khassawneh, M., Khader, Y., \& Dahl, E. (2009). Sex preference and interest in preconception sex selection: a survey among pregnant women in the north of Jordan. Human Reproduction, 24(7), 1665-1669. doi:https://doi.org/10.1093/humrep/dep080

Al-Abbas, L. S., \& Haider, A. S. (2020). The representation of homosexuals in Arabic-language news outlets. Equality, Diversity Inclusion: An International Journal. doi:https://doi.org/10.1108/edi-05-2020-0130

Al-Badayneh, D. M. (2012). Violence against women in Jordan. Journal of family violence, 27(5), 369-379. doi:https://doi.org/10.1007/s10896-012-9429-1

Al-Kholy, J. (2006). 'Ta'addud al-Zawjaat wa Hikmatuhu fil Islam,' (Multiple Marriages In Islam \& It's Wisdom). Journal of the Islamic University of Medina, 46, 222-231.

Al-Maaitah, R., Al-Maaitah, H., Olimat, H., \& Gharaibeh, M. (2011). Arab women and political development. Journal of International Women's Studies, 12(3), 7-26.

Alkhammash, R. (2020). Discursive representation of the EU in Brexit-related British Media. GEMA Online ${ }^{\circledR}$ Journal of Language Studies, 20(1), 77-91. doi:https://doi.org/10.17576/gema-2020-2001-05

Allam, R. (2008). Countering the negative image of Arab women in the Arab media: toward a "Pan Arab Eye" Media Watch Project. Policy Brief, The Middle East Institute, 15, 1-8.

Alomosh, A. F., \& Al Hourani, M. A. K. (2017). Domestic Violence in the Arab World. In E. S. Buzawa \& C. G. Buzawa (Eds.), Global Responses to Domestic Violence (pp. 291307). Cham: Springer International Publishing. 
Baker, P., \& Potts, A. (2013). 'Why do white people have thin lips?'Google and the perpetuation of stereotypes via auto-complete search forms. Critical Discourse Studies, 10(2), 187-204. doi:https://doi.org/10.1080/17405904.2012.744320

Burgess, D., \& Borgida, E. (1999). Who women are, who women should be: Descriptive and prescriptive gender stereotyping in sex discrimination. Psychology, public policy, law, 5(3), 665-692. doi:https://doi.org/10.1037/1076-8971.5.3.665

Buttle, F. (1992). Shopping motives constructionist perspective. Service Industries Journal, 12(3), 349-367. doi:https://doi.org/10.1080/02642069200000044

Cohen, O., \& Savaya, R. (1997). "Broken glass": The divorced woman in Moslem Arab society in Israel. Family process, 36(3), 225-245. doi:https://doi.org/10.1111/j.15455300.1997.00225.x

Davison, R. C. (2012). Critically thinking about the brain and gender differences. In B. Bogue \& E. T. Cady (Eds.), Applying research to practice resources. New York: Academia Press.

de Boise, S. (2015). Boys Don’t Cry? Men, Masculinity and Emotions. In S. De Boise (Ed.), Men, Masculinity, Music and Emotions (pp. 45-69). London: Palgrave Macmillan.

Douki, S., Nacef, F., Belhadj, A., Bouasker, A., \& Ghachem, R. (2003). Violence against women in Arab and Islamic countries. Archives of women's mental health, 6(3), 165171. doi:https://doi.org/10.1007/s00737-003-0170-x

Dreber, A., \& Johannesson, M. (2008). Gender differences in deception. Economics Letters, 99(1), 197-199. doi:https://doi.org/10.1016/j.econlet.2007.06.027

Eagly, A. H., \& Steffen, V. J. (1984). Gender stereotypes stem from the distribution of women and men into social roles. Journal of personality social psychology, 46(4), 735-754. doi:https://doi.org/10.1037/0022-3514.46.4.735

Eisend, M. (2019). Gender Roles. Journal of Advertising, 48(1), 72-80. doi:https://doi.org/10.4324/9781351208314-12

El Gilany, A.-H., \& Shady, I. (2007a). Determinants and causes of son preference among women delivering in Mansoura, Egypt. Eastern Mediterranean health journal, 13(1), 119-128. doi:https://doi.org/10.21474/ijar01/1075

El Gilany, A., \& Shady, E. (2007b). Determinants and causes of son preference among women delivering in Mansoura, Egypt. Eastern Mediterranean Health Journal,, 13(1), 119128.

Fairclough, N. (2001). Language and power (Vol. 2nd). New York; Harlow, Eng: Longman.

Fischer, A. H., \& Manstead, A. S. (2000). The relation between gender and emotions in different cultures. In A. H. Fischer (Ed.), Gender emotion: Social psychological perspectives (Vol. 1, pp. 71-94). Cambridge: Cambridge University Press.

Ghanem, R. (2011). Men shorter than wives still carry social stigma. ARAB NEWS. Retrieved from https://www.arabnews.com/node/387613

Ghoussoub, M. (1987). Feminism-or the eternal masculine-in the Arab world. New Left Review, 161(1), 3-18.

Glick, P., \& Fiske, S. T. (1996). The ambivalent sexism inventory: Differentiating hostile and benevolent sexism. Journal of personality social psychology, 70(3), 491-512. doi:https://doi.org/10.1037/0022-3514.70.3.491

Goodwin, J. (2003). Price of honor: Muslim women lift the veil of silence on the Islamic world. Boston: Plume Group.

Google. (2019). Autocomplete policies. Retrieved from https://support.google.com/websearch/answer/7368877?hl=en

Haider, A. S. (2019a). The Representation of Al-Megrahi's Release in Arabic and English Newspapers in 2009 and 2010: A Corpus-assisted Discourse Study. Dirasat, Human Social Sciences, 46(1 Supplement 2), 297-317. 
Haider, A. S. (2019b). Syrian-Lebanese Relations: A Corpus-based Critical Discourse Analysis of Bashar Al-Assad's Speeches and Interviews. Dirasat, Human Social Sciences, 46(4), 551-570.

Haider, A. S. (2019c). Using Corpus Linguistic Techniques in (Critical) Discourse Studies Reduces but does not Remove Bias: Evidence from an Arabic Corpus about Refugees. Poznan Studies in Contemporary Linguistics, 55(1). doi: https://doi.org/10.1515/psicl2019-0004

Haider, A. S., \& Hussein, R. F. (2020). Analysing headlines as a way of downsizing news corpora: Evidence from an Arabic-English comparable corpus of newspaper articles. Digital Scholarship in the Humanities, 35(4), 826-844. doi:https://doi.org/10.1093/llc/fqz074

Haider, A. S., \& Olimy, S. (2019). The Representation of Laji'een (Refugees) and Muhajireen (Migrants) in the Headlines of Jordan News Agency (PETRA). International Journal for the Semiotics of Law-Revue internationale de Sémiotique juridique, 32, 155-186. doi:10.1007/s11196-018-9550-4

Hauser, R. M., \& Featherman, D. L. (2013). The process of stratification: Trends and analyses. New York: Academic Press.

Hearn, J. (1993). Emotive subjects: Organizational men, organizational masculinities and the (de) construction of "emotions.". In S. Fineman (Ed.), Emotion in organizations (pp. 142-166). London: Sage Publications.

Hilton, J. L., \& Von Hippel, W. (1996). Stereotypes. Annual review of psychology, 47(1), 237271. doi:https://doi.org/10.1146/annurev.psych.47.1.237

Husain, R. T., Ahmad, A., Kara, S. A., \& Alwi, Z. (2019). Polygamy in the Perspective of Hadith: Justice and Equality among Wives in A Polygamy Practice. MADANIA: JURNAL KAJIAN KEISLAMAN, 23(1), 93-104. doi: https://doi.org/10.29300/madania.v23i1.1954

Inhorn, M. C. (2013). Why me? Male infertility and responsibility in the Middle East. Men Masculinities, 16(1), 49-70. doi:https://doi.org/10.1177/1097184x12468098

Internet World Stats. (2019). Top 20 countries with the highest number of internet users Internet World Stats. Retrieved from https://www.internetworldstats.com/top20.htm

Joharry, S. A. (2020). Examining Malaysian Public Letters to Editor on COVID-19 Pandemic: A Corpus-assisted Discourse Analysis. GEMA Online ${ }^{\circledR}$ Journal of Language Studies, 20(3), 242-260. doi:https://doi.org/10.17576/gema-2020-2003-14

Judd, C. M., \& Park, B. (1993). Definition and assessment of accuracy in social stereotypes. Psychological review, 100(1), 109. doi:https://doi.org/10.1037/0033-295x.100.1.109

Kajackaite, A., \& Gneezy, U. (2017). Incentives and cheating. Games Economic Behavior, 102, 433-444. doi:https://doi.org/10.1016/j.geb.2017.01.015

Kia, A. (2019). The concept of responsibility of men and women in Islam. Art Human Open Acc J, 3(5), 247-251. doi:10.15406/ahoaj.2019.03.00137

Kluwer, E. S., Heesink, J. A., \& Van de Vliert, E. (1996). Marital conflict about the division of household labor and paid work. Journal of Marriage the Family, 58, 958-969. doi:https://doi.org/10.2307/353983

Matharu, H. (2015). Wife 'divorces husband for being too short'. Independent. Retrieved from https://www.independent.co.uk/news/world/saudi-arabian-woman-divorces-husbandfor-being-too-short-a6676461.html

Mohler Jr, R. A. (2015). We cannot be silent: speaking truth to a culture redefining sex, marriage, and the very meaning of right and wrong. Nashville, Tennessee: Thomas Nelson.

Office of the United Nations High Commissioner for Human Rights/ OHCHR. (2014). Gender stereotypes and Stereotyping and women's rights. Retrieved from 
https://www.ohchr.org/Documents/Issues/Women/WRGS/OnePagers/Gender_stereoty ping.pdf

Ottaway, M. (2004). Women's rights and democracy in the Arab world. Carnegie Endowment for International Peace Washington, DC.

Patrick, W. L. (2019). Why Some Younger Men Want to Date Older Women. Psychologytoday. Retrieved from https://www.psychologytoday.com/intl/blog/why-bad-looksgood/201908/why-some-younger-men-want-date-older-women

Perry-Jenkins, M., \& Folk, K. (1994). Class, couples, and conflict: Effects of the division of labor on assessments of marriage in dual-earner families. Journal of Marriage the Family, 56, 165-180. doi:https://doi.org/10.2307/352711

Prentice, D. A., \& Carranza, E. (2002). What women and men should be, shouldn't be, are allowed to be, and don't have to be: The contents of prescriptive gender stereotypes. Psychology of women quarterly, 26(4), 269-281. doi:https://doi.org/10.1111/14716402.t01-1-00066

Reagan, B., \& Blaxall, M. (1976). Women and the Workplace: The Implications of Occupational Segregation. Chicago: University of Chicago Press.

Rehman, J. (2007). The sharia, Islamic family laws and international human rights law: Examining the theory and practice of polygamy and talaq. International Journal of Law, Policy the Family, 21(1), 108-127. doi:https://doi.org/10.1093/lawfam/ebl023

Roy, S., \& Ayalon, L. (2019). Age and Gender Stereotypes Reflected in Google's "Autocomplete" Function: The Portrayal and Possible Spread of Societal Stereotypes. The Gerontologist, XX(XX), 1-9. doi:https://doi.org/10.1093/geront/gnz172

Rubery, J. (2017). Why is women's work low-paid? Establishing a framework for understanding the causes of low pay among professions traditionally dominated by women. Oxfam Discussion Papers, Oxford.

Sabir, Y. (2008). Superiority of Muslim Women Over Hoors (Hoor al-Ayn/Houris) of Jannah (Paradise). Retrieved from https://www.scribd.com/doc/4851831/Superiority-ofMuslim-Women-Over-Hoors-Hoor-al-Ayn-Houris-of-Jannah-Paradise

Said-Foqahaa, N., \& Maziad, M. (2011). Arab women: Duality of deprivation in decisionmaking under patriarchal authority. Hawwa, 9(1-2), 234-272. doi:https://doi.org/10.1163/156920811x578539

Schein, V. E. (1973). The relationship between sex role stereotypes and requisite management

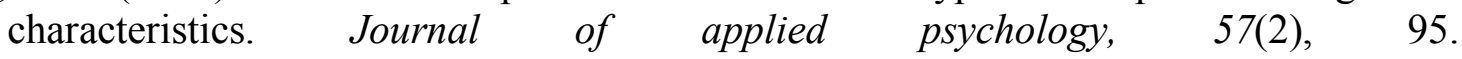
doi:https://doi.org/10.1037/h0037128

Scherhorn, G., Reisch, L. A., \& Raab, G. (1990). Addictive buying in West Germany: An empirical study. Journal of consumer policy, 13(4), 355-387. doi:https://doi.org/10.1007/bf00412336

Serota, K. B., Levine, T. R., \& Boster, F. (2010). The prevalence of lying in America: Three studies of self-reported lies. Human Communication Research, 36(1), 2-25. doi:https://doi.org/10.1111/j.1468-2958.2009.01366.x

Sharaf, M. F., Rashad, A. S., \& Mansour, E. I. (2019). Son preference and child under nutrition in the Arab countries: is there a gender bias against girls? Middle East Development Journal, 11(2), 199-219. doi:https://doi.org/10.1080/17938120.2019.1664837

Stangor, C. (2000). Stereotypes and prejudice: Essential readings. United Kingdom: Routledge StatCounter. (2019). Search Engine Market Share Worldwide. StatCounter Retrieved from https://gs.statcounter.com/search-engine-market-share

Turner, J. C. (2010). Social categorization and the self-concept: A social cognitive theory of group behavior. In J. C. Turner, and E. Lawler. (Ed.), Advances in group processes: Theory and research (pp. 77-122). Greenwich, CT: JAI Press. 
Wanjek, C. (2003). Bad medicine: misconceptions and misuses revealed, from distance healing to vitamin $O$. Hoboken, NJ: John Wiley \& Sons.

Wodak, R., \& Ludwig, C. (1999). Introduction. In R. Wodak, and Christoph Ludwig. (Ed.), Challenges in a Changing World (pp. 11-19). Vienna: Passagen Verlag.

Woodruffe, H. R. (1997). Compensatory consumption: why women go shopping when they're fed up and other stories. Marketing Intelligence Planning, 14(2), 325-334. doi:https://doi.org/10.1108/02634509710193172

Zaidi, T. (2016). Polygamy: In The Perspective of Islam. Social Sciences International Research Journal, 2(1), 201-205.

\section{ABOUT THE AUTHORS}

Linda S. Al-Abbas is an Assistant Professor at the Department of English Language and Literature, Middle East University/ Jordan. Dr. Al-Abbas received her PhD in Linguistics from the University of Jordan. Her main areas of interest include gender studies, discourse analysis, semantics and translation.

Ahmad S. Haider received his $\mathrm{PhD}$ in Linguistics from the University of Canterbury/ New Zealand. His current research focuses on how political events are socially, discursively and linguistically represented in media combining Corpus Linguistics and (Critical) Discourse Analysis. His main areas of interest include corpus linguistics, discourse analysis, pragmatics, and translation studies. Dr. Haider has built different large Arabic and English corpora. He professionally masters different Corpus Linguistic software packages.

http://orcid.org/0000-0002-7763-201X

Riyad F. Hussein is a Professor in the Department of English Language and Translation at the Applied Science Private University, Amman, Jordan. He obtained his PhD in linguistics from the State University of New York (SUNY) at Buffalo. He has published extensively in international journals such as Language Problems and Language Planning, English for Special Purposes, Language Sciences, World Englishes, Babel and META. His research interests include bilingualism, code-switching, second language acquisition, translation and interpreting. 